\title{
Structural, morphological and optical properties of Mn doped ZnS nanocrystals
}

\section{(Propriedades estruturais, morfológicas e ópticas de nanocristais de ZnS dopado com $\mathrm{Mn}$ )}

\author{
V. D. Mote ${ }^{1}$, Y. Purushotham ${ }^{2}$, B. N. Dole ${ }^{*}$ \\ ${ }^{1}$ Advanced Materials Research Laboratory, Department of Physics, Dr. B. A. Marathwada University, \\ Aurangabad-431 004, India \\ ${ }^{2}$ Centre for Materials for Electronics Technology, IDA Phase-III, Cherlaplly, \\ Hyderabad-500 051, India \\ dolebn_phys@yahoo.in
}

\begin{abstract}
Mn doped $\mathrm{ZnS}$ samples with composition formula $\mathrm{Zn}_{1-\mathrm{x}} \mathrm{Mn}_{\mathrm{x}} \mathrm{S}$ where $\mathrm{x}=0.00,0.02,0.05$ and 0.10 were prepared by chemical method. Samples characterized for its structural, morphological and optical properties by X-ray diffraction (XRD), transmission electron microscopy (TEM), Fourier transform infrared spectroscopy (FTIR) and UV-vis spectrometer. XRD patterns confirm cubic zinc blend structure with no secondary phases for pure and Mn doped ZnS. Lattice constant value increases slightly with Mn concentration due to the substitution of Mn in ZnS lattice. TEM images show that the particles have spherical in shape with an average particle size between 3-4 nm. The chemical species of the grown crystals are identified by FTIR spectra. Optical absorption spectra show decrement in band gap with increasing Mn concentration.
\end{abstract}

Keywords: ZnS, nanocrystals, particle size, surface morphology, optical properties.

\section{Resumo}

\begin{abstract}
Amostras de $\mathrm{ZnS}$ dopadas com Mn de composição $\mathrm{Zn}{ }_{1-x} \mathrm{Mn}_{x} \mathrm{~S}, x=0$, 0,02, 0,05 e 0,10 foram preparadas por método químico e caracterizadas estructural, morfológica e ópticamente por difração de raios $X$ (DRX), microscopia eletrônica de transmissão e espectroscopia no infravermelho (FTIR) e espectrofotometria de absorção óptica UV-VIS. Os difratogramas de raios X confirmam a estrutura cúbica sem fases secundárias no ZnS puro e no dopado. O valor do parâmetro de rede com o aumento na concentração de manganês devido à substituição do manganês na rede do ZnS. Imagens de microscopia eletrônica de transmissão mostram que as partículas são esféricas com tamanho médio 3-4 $\mathrm{nm}$. As espécies químicas no cristal foram identificadas pelos espectros FTIR. Os espectros de absorção óptica mostram decréscimo no gap da banda com o aumento da concentração de Mn.

Palavras-chave: ZnS, nanocristais, tamanho de partícula, morfologia de superficie, propriedades ópticas.
\end{abstract}

\section{INTRODUCTION}

Semiconductor nanocrystals have been extensively studied by scientists owing to their potential applications in recent years [1,2]. Zinc sulfide is an important material owing to numerous applications. The theoretical band gap of this II-VI compound semiconductor is $3.6 \mathrm{eV}$ [3]. Behavior of these materials is different from bulk semiconductors due to increase in particle size, band structure changes, increase in band gap and edges of the band split into discrete energy levels. Divalent substitution such as $\mathrm{Mn}^{2+}, \mathrm{Cu}^{2+}$ and $\mathrm{Ag}^{2+}$ with $\mathrm{ZnS}$ semiconductors and their photo physical and photochemical properties were investigated [4-9]. The photoluminescence mechanism of $\mathrm{ZnS}$ nanocrystals doped with other metal ions is very complex. Smaller particles have higher surface to volume ratio and more surface state therefore contain more accessible carriers for photoluminescence [10]. This indicates that surface state is very important to the physical properties, especially the optical properties of nanoparticles. Divalent elements like $\mathrm{Mn}^{2+}$ ions doped $\mathrm{ZnS}$ nanocrystals can be obtained in many ways such as spray-based method [11], mechanochemical route [12], ultrasonic radiation of solution [13], Gama irradiation method [14], chemical precipitation method [15], organic metallic method [16], polymerization [17], reverse Michelle method [18] and sol-gel method [19]. We preferred chemical method for the preparation of $\mathrm{Mn}$ doped $\mathrm{ZnS}$ nanocrystals to get the cluster formation. This method is simple, low cost and availability of the equipments.

The aim of this work is to study the effect of $\mathrm{Mn}^{2+}$ ions doping on synthesis, structural, morphological and optical properties of $\mathrm{ZnS}$ nanoparticles. Characterization techniques employed to characterize the materials were UV-Visible, $\mathrm{XRD}$ and TEM. Crystal structure and average grain size were measured using XRD. TEM used to study particle size and morphology. FTIR used to study quantum size effect in $\mathrm{ZnS}$ nanoparticles. 


\section{EXPERIMENTAL}

Samples with chemical formula $\mathrm{Zn}_{1-\mathrm{x}} \mathrm{Mn}_{\mathrm{x}} \mathrm{S}$, where $\mathrm{x}=$ $0.00,0.02,0.05$ and 0.10 , were prepared by chemical method using manganese acetate, Zinc acetate and sodium sulfide in aqueous medium without using any other reagent. In this, 20 $\mathrm{mL}$ of $1 \mathrm{M}$ zinc acetate solution was diluted to $80 \mathrm{~mL}$ using distilled water and $20 \mathrm{~mL}$ of manganese acetate solution was added dropwise, followed by drop wise addition of $20 \mathrm{~mL}$ of $1 \mathrm{M}$ sodium sulfide under vigorous stirring to obtain $\mathrm{pH}$ 13.5. A white precipitate was obtained which was separated by centrifugation. The precipitate was washed several times with water and ethanol. The precipitate was then dried under vacuum at $60{ }^{\circ} \mathrm{C}$ to get the powder samples. Mn doped-ZnS nanocrystals were prepared at room temperature by mixing calculated amounts of zinc acetate solution and manganese acetate solution followed by dropwise addition of saturated solution of Sodium sulfide up to $\mathrm{pH}$ 13.5. The mixture was vigorously stirred for $2 \mathrm{~h}$. The precipitate was filtered from the reaction mixture and washed several times with ethanol to remove all sodium particles. The wet precipitate was then dried. The samples were characterized by X-ray diffraction (PW-3710), Transmission electron microscopy (TEM), FTIR spectroscopy (JASCO FTIR-4100) and UV-VIS spectroscopy.

\section{RESULTS AND DISCUSSION}

\section{X-ray diffraction study}

$\mathrm{X}$-ray diffraction (XRD) patterns of the synthesized $\mathrm{ZnS}$ and $\mathrm{Mn}$ doped $\mathrm{ZnS}$ samples are shown in Fig. 1. All XRD peaks are matched well with JCPDS No. 77- 2100 and were indexed as cubic Zinc blend structure. It can be seen from the figure that XRD peaks are broadened with three main peaks corresponding to (111), (220) and (311) planes. Mn

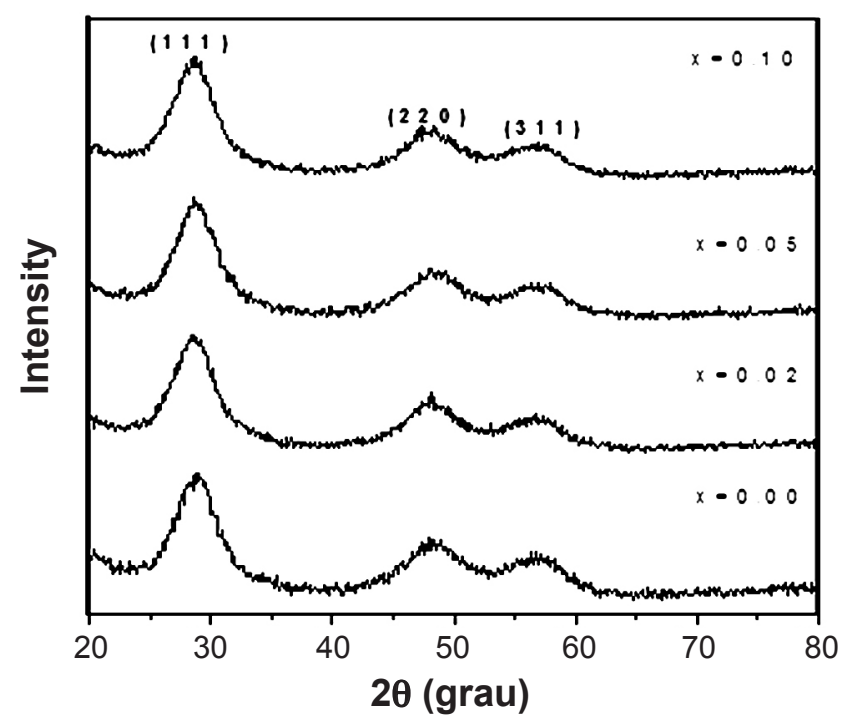

Figure 1: X-ray diffraction patterns of Mn doped and undoped $\mathrm{ZnS}$ samples.

[Figura 1: Difratogramas de raios X de $\mathrm{ZnS}$ e de $\mathrm{ZnS}$ dopado com Mn.] doped $\mathrm{ZnS}$ samples also showing Zinc blend structure of $\mathrm{ZnS}$ which confirms the formation of $\mathrm{Mn}$ doped $\mathrm{ZnS}$ solid solution and there is no formation of Mn precipitation or secondary phases. Youn et al. [24] reported that for higher concentration of Mn doping in $\mathrm{ZnS}$ results separation of $\mathrm{Mn}$ atoms from the $\mathrm{ZnS}$ matrix.

The lattice constant 'a' was calculated using the following relation

$$
\frac{1}{\mathrm{~d}_{\mathrm{hkl}}^{2}}=\left(\frac{\mathrm{h}^{2}+\mathrm{k}^{2}+\mathrm{l}^{2}}{\mathrm{a}^{2}}\right)
$$

We observed that ' $a$ ' slightly increases for Mn doped nanocrystals as shown in Fig. 2. This may be due to the substitution of $\mathrm{Mn}^{2+}$ ions in $\mathrm{Zn}^{2+}$ ions. Since the ionic radius of $\mathrm{Mn}^{2+}$ ion $\left(0.80 \mathrm{~A}^{0}\right)$ is larger than that of $\mathrm{Zn}^{2+}$ ion $(0.74$ $\mathrm{A}^{0}$ ). The volume of unit cell was calculated using the lattice parameter ' $a$ ' and it is found that the unit of volume cell enhances with increasing Mn concentration as shown in Fig. 3. This indicates that $\mathrm{Mn}^{2+}$ ions go to $\mathrm{Zn}$ site in the structure due to larger ionic radius. The values of volume of unit cell are tabulated in Table I. X-ray density was calculated using the following relation.

Table I - Lattice constant, crystallite size, volume of unit cell and X-ray density of Mn doped $\mathrm{ZnS}$ nanocrystals.

[Tabela I - Constante de rede, tamanho de cristalito, volume da célula unitária e densidade (DRX) de nonocristai de ZnS dopados com Mn.]

\begin{tabular}{lcccc}
\hline Samples & a $(\AA)$ & $\begin{array}{c}\text { crystallite Size } \\
(\mathrm{nm})\end{array}$ & $\begin{array}{l}\text { Volume } \\
(\AA)^{3}\end{array}$ & $\begin{array}{c}\text { X- ray density } \\
\left(\mathrm{g} / \mathrm{cm}^{3}\right)\end{array}$ \\
\hline 0.00 & 5.3706 & 02.89 & 154.91 & 4.1772 \\
0.02 & 5.3711 & 02.65 & 154.95 & 4.1671 \\
0.05 & 5.3725 & 02.57 & 155.07 & 4.1505 \\
0.10 & 5.3734 & 02.50 & 155.15 & 4.1261 \\
\hline
\end{tabular}

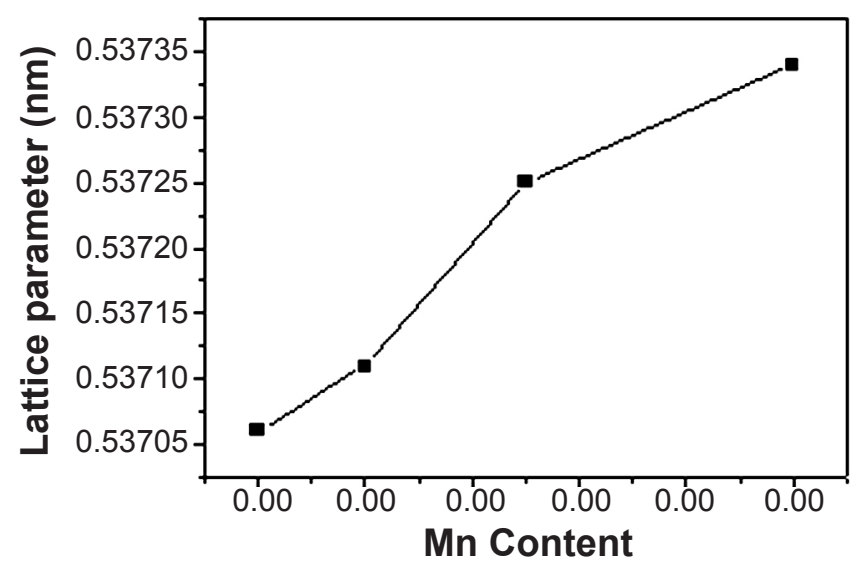

Figure 2: Lattice parameter Vs Mn content of pure and Mn doped $\mathrm{ZnS}$ samples.

[Figura 2: Parâmetro de rede de $\mathrm{ZnS}$ e de $\mathrm{ZnS}$ dopado com Mn.] 


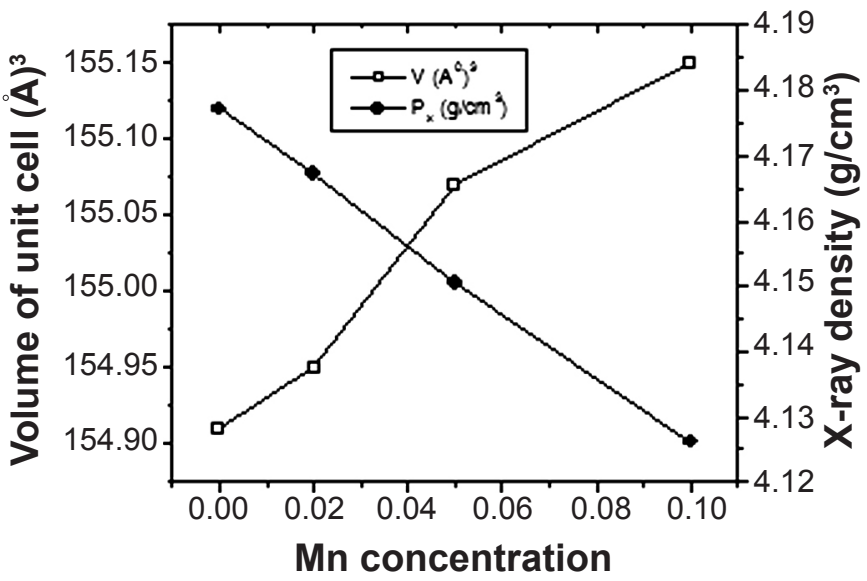

Figure 3: Volume of unit cell and X-ray density with Mn content of $\mathrm{ZnS}$ samples.

[Figure 3: Volume da célula unitária e densidade (DRX) em função do teor de Mn.]

$$
\rho_{\mathrm{x}}=\frac{\mathrm{nM}}{\mathrm{N}_{\mathrm{A}} \mathrm{V}}
$$

where $\mathrm{n}$ is number of atoms per unit cell, $\mathrm{M}$ is molecular weight of the samples, $N_{A}$ is Avogadro's number and $V$ is unit cell volume. The values of X-ray density are also tabulated in Table I. X-ray density decreases with increasing $\mathrm{Mn}$ concentration. This decrease was attributed to the decrease in molecular weight. Since atomic weight of Mn ion (58.93 $\mathrm{amu})$ is smaller than that of $\mathrm{Zn}$ ion $(65.37 \mathrm{amu})$. The plots of unit cell volume and X-ray density with Mn content are shown in Fig. 3.

The average crystallite size of Mn doped $\mathrm{ZnS}$ samples was determined by extra broadening of the X-ray diffraction peaks of the samples using the Debye-Scherrer's formula using following relation

$$
\mathrm{D}=\frac{\mathrm{K} \lambda}{\beta_{\mathrm{hkl}} \operatorname{Cos} \theta}
$$

where $\mathrm{D}$ is the crystallite size, $\mathrm{K}$ is the shape factor $(0.9), \lambda$ is the wavelength of $\mathrm{Cuk}_{\alpha}$ radiation, $\beta_{\text {hkl }}$ is the instrumental corrected integral breadth of the reflection (in radians) located at $2 \theta$ and $\theta$ is the angle of reflection (in degree). It is found that the average crystallite size is in the range of 3-2 $\mathrm{nm}$ and values are depicted in Table I. It is observed that the average crystallite size decreases with increasing $\mathrm{Mn}$ concentration. It means the $\mathrm{Zn}^{2+}$ ions are replaced by $\mathrm{Mn}^{2+}$ ions in the $\mathrm{ZnS}$ matrix. It may be due to the induced growth of the particles and enhancement of surface area to volume ratio in the system.

\section{Morphological studies}

It is necessary to know an exact particle size and structures of nanomaterials by direct measurement, such as transmission electron microscope (TEM), which can
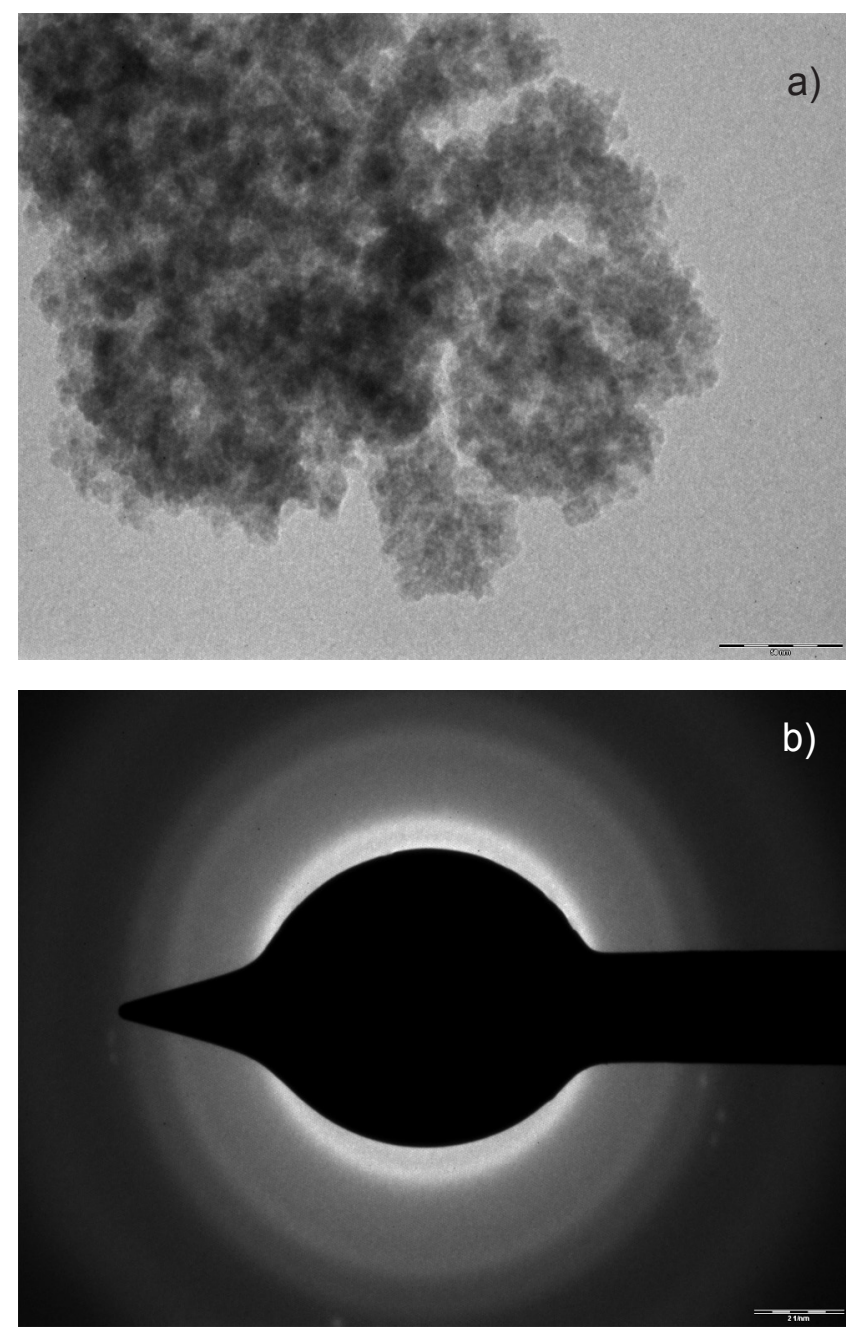

Figure 4: Transmission electron microscope image (a) and Selected Area Electron Diffraction (SAED) image of $\mathrm{ZnS}$ nanocrystals.

[Figura 4: Imagens de microscopia eletrônica de transmissão (a) e difraão de elétrons de área selecionada (b) de nanocristais de ZnS.]

reveal the particle size, shape and orientation of the $\mathrm{Mn}$ doped $\mathrm{ZnS}$ nanoparticles. Electron diffraction patterns at different regions on the TEM grid were recorded for pure $\mathrm{ZnS}$ sample. We did not find any other diffraction rings that cannot be indexed by sphalerite structure. Fig. 4a shows TEM image of pure ZnS sample. TEM image shows that particles are nearly in spherical shape and having average particle size of 3-4 $\mathrm{nm}$ for the pure $\mathrm{ZnS}$ sample. This value is consistent with the XRD result of pure $\mathrm{ZnS}$ sample. Fig. 4(b) shows the corresponding selected area electron diffraction (SAED) pattern. The SAED pattern corresponds to reflections from three crystal planes which indicate (111), (220) and (311). It is observed that the particles are well separated and evidenced with few agglomerations.

The agglomeration was probably due to the particles in a concentrated sample could end up in association during grid drying in the TEM sample processing protocol [25]. The spherical shape of the particles is also evidenced from the Fig. $4 \mathrm{~b}$, which presents magnified view of nanocrystals. 
Table II - Assignment of frequencies of FTIR spectra of Mn doped ZnS nanocrystals. [Tabela II - Frequências dos espectros FTIR de nanocristais de ZnS dopados com Mn.]

\begin{tabular}{lllll}
\hline $\begin{array}{l}\mathrm{x}=0.00 \\
\left(\mathrm{~cm}^{-1}\right)\end{array}$ & $\begin{array}{l}\mathrm{x}=0.02 \\
\left(\mathrm{~cm}^{-1}\right)\end{array}$ & $\begin{array}{l}\mathrm{x}=0.05 \\
\left(\mathrm{~cm}^{-1}\right)\end{array}$ & $\begin{array}{l}\mathrm{x}=0.10 \\
\left(\mathrm{~cm}^{-1}\right)\end{array}$ & Assignment of frequencies \\
\hline 439.60 & 404.59 & 439.60 & 483.87 & Asymmetric bending \\
668.15 & 658.88 & 668.15 & 658.88 & ZnS stretching \\
913.18 & 903.91 & 905.68 & 921.421 & Additional asymmetric stretching \\
1008.92 & 1027.45 & 1027.45 & 1018.18 & Shoulder with asymmetric stretching \\
1219.97 & 1228.20 & 1219.97 & 1245.71 & Symmetric stretching \\
1350.72 & 1350.72 & 1350.72 & 1350.72 & Weak additional stretching \\
1420.73 & 1429.99 & 1429.99 & 1420.73 & C=O Asymmetric stretching \\
1561.77 & 1552.50 & 1561.77 & 1570.00 & C=O Symmetric stretching \\
2350.37 & 2358.61 & 2358.61 & 2358.51 & Weak additional bands \\
3436.51 & 3427.25 & 3506.52 & 3436.51 & O-H stretching \\
\hline
\end{tabular}

\section{FTIR study}

Fig. 5 shows FTIR spectra of pure and Mn doped ZnS samples. The values of IR peaks of all samples are tabulated in Table II. It clearly shows a broad peak at $3400-3600 \mathrm{~cm}^{-1}$ due to $\mathrm{O}-\mathrm{H}$ stretching has been observed in all samples because of some absorbed moisture.

The samples at room temperature show characteristic peaks at $612,865,1004,1119$, and some other associated peaks are shown in Fig. 5. It is observed that the peak at $612 \mathrm{~cm}^{-1}$ is assigned to the $\mathrm{ZnS}$ band (i.e. corresponding to sulfides) for all samples. FTIR spectra of our samples yield the bands which are in good agreement with the reported values [26]. The change is observed in values when $\mathrm{Mn}$ content is increased it means that the formation of nanophase in the prepared samples. IR absorption peaks at 900-1500 $\mathrm{cm}^{-1}$ are due to the oxygen stretching and bending frequency. The additional weak bands and shoulders at 2941, 2847, 2353, 1634 and $1409 \mathrm{~cm}^{-1}$ are observed. It may be due to the microstructure formation of the samples. Bands around

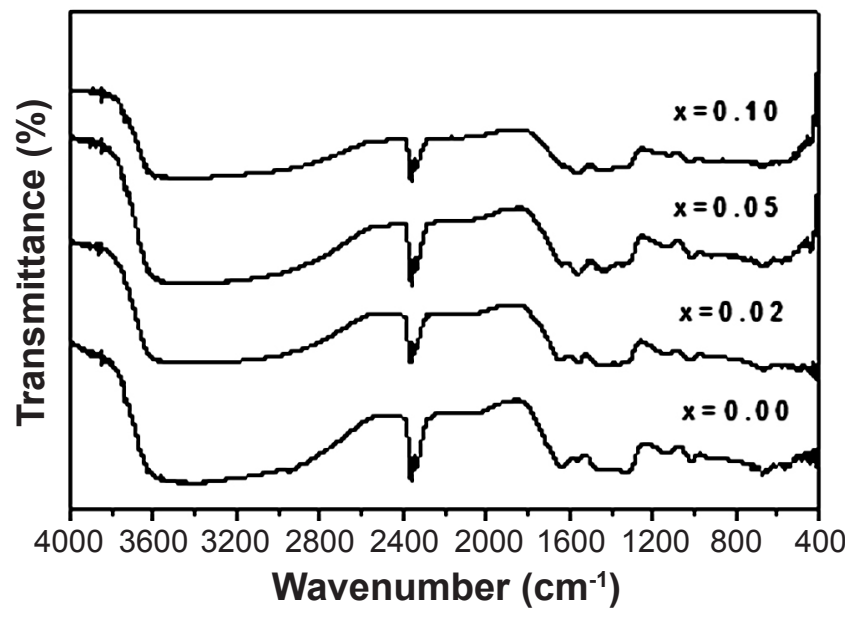

Figure 5: FTIR spectra of pure and $\mathrm{Mn}$ doped $\mathrm{ZnS}$ nanocrystals. [Figura 5: Espectros FTIR de nanocristais de ZnS puro e dopado com $\mathrm{Mn}$.]
1200 and $1100 \mathrm{~cm}^{-1}$ are due to the characteristics frequency of inorganic ions. Due to low temperature, weak additional bands are observed at 992, 984 and $865 \mathrm{~cm}^{-1}$. These modes indicate the presence of resonance interaction between vibrational modes of sulfide ions in the crystals [27].

\section{Optical studies}

The absorption spectra of pure and $\mathrm{Mn}$ doped $\mathrm{ZnS}$ samples are shown in Fig. 6. The absorption spectra of Mn doped samples are different than of undoped sample. It is due to effect of doped ions on band structure of the host material. The absorption peaks and edges of the samples vary with changing in the molar concentration of $\mathrm{Mn}^{2+}$ ions. $\mathrm{ZnS}$ has good absorption for light in the wave length of 220-350 nm [28]. Semiconductor crystallites in the diameter range of a few nanometers show a three dimensional quantum size effect in their electronic structure. The quantum size effects on the band gap absorption energy can be measured by UVVis absorption spectroscopy.

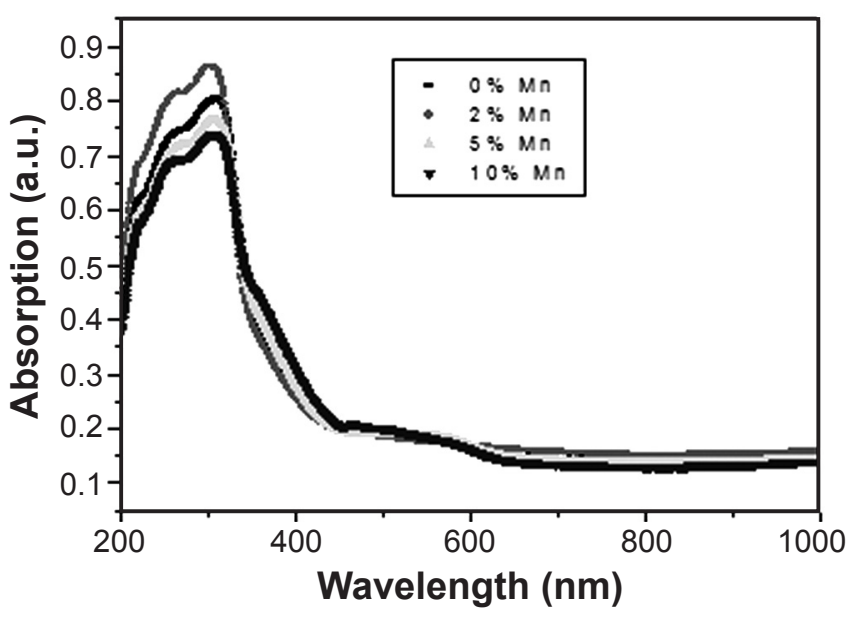

Figure 6: UV-VIS spectra of pure and Mn doped $\mathrm{ZnS}$ samples. [Figura 6: Espectros UV-VIS de amostras de ZnS pura e dopada com Mn.] 

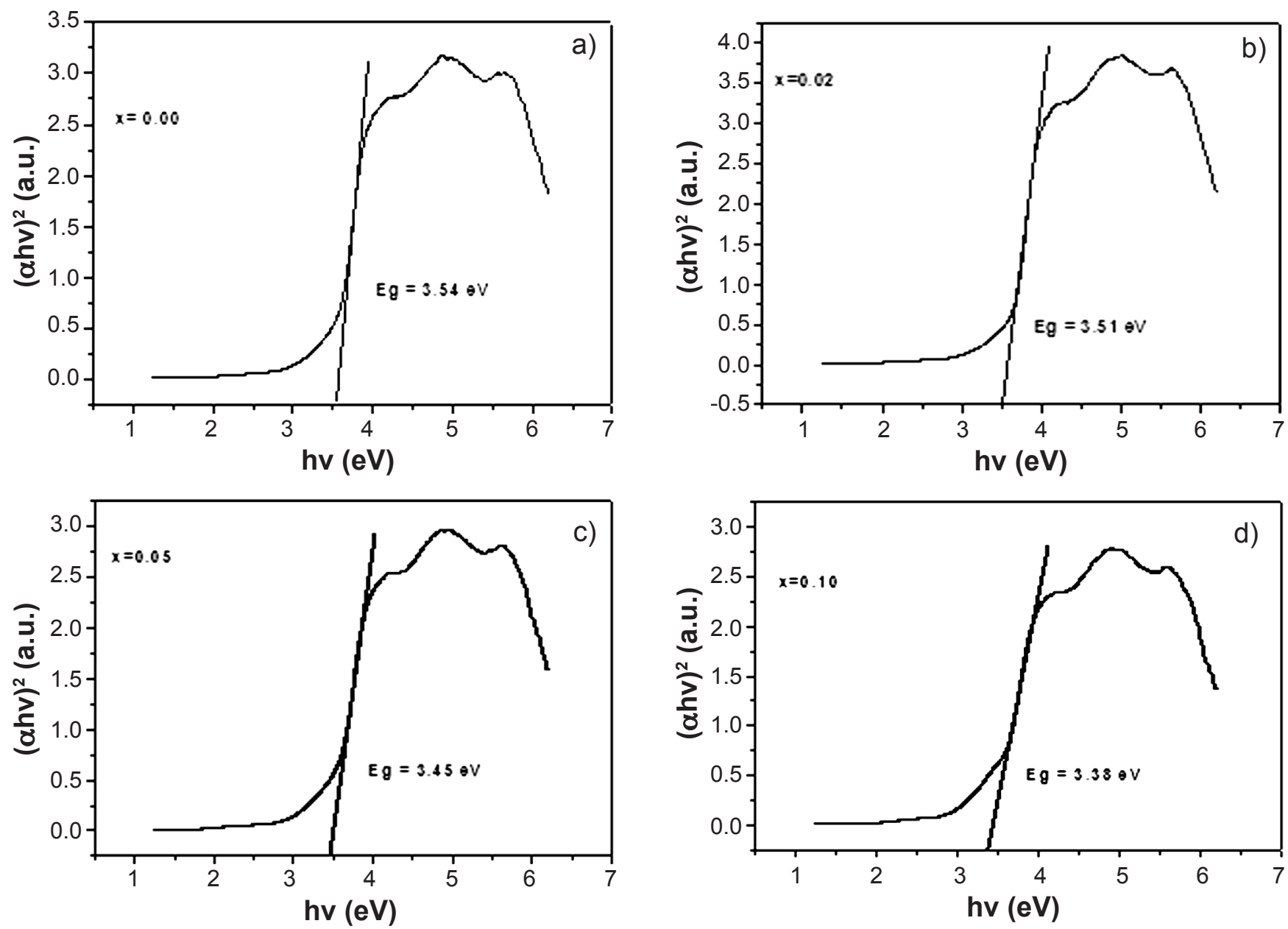

Figure 7: The plots of $(a h v)^{2}$ vs. photon energy of Mn doped and undoped $\mathrm{ZnS}$ samples.

[Figura 7: Gráficos de $(a h v)^{2}$ vs. energia do fóton de amostras de ZnS pura e dopada com Mn. ]

It is well known that the cubic $\mathrm{ZnS}$ is a direct gap semiconductor [29]. The relation between the absorption coefficient $(\alpha)$ and incident photon energy (hv) allowed direct transition is [30]:

$$
\alpha \mathrm{h} v=\mathrm{A}\left(\mathrm{h} v-\mathrm{E}_{\mathrm{g}}\right)^{1 / 2}
$$

where $\mathrm{A}$ is the constant and $\mathrm{E}_{\mathrm{g}}$ is the energy band gap of the material.

The plots of $(\alpha h v)^{2}$ versus hv for the undoped $\mathrm{ZnS}$ and $\mathrm{Mn}$ doped $\mathrm{ZnS}$ nanocrystals are represented in Fig. 7. By extra plotting the straight portion of the graph on hv axis at $\alpha=0$, it is found that the band gap of the undoped and Mn doped $\mathrm{ZnS}$ nanoparticles for concentrations $0.00,0.02,0.05$ and 0.10 to be $3.54,3.51,3.45$ and $3.38 \mathrm{eV}$, respectively. These values can be compared with band gap values of 3.38-3.54 $\mathrm{eV}$ at room temperature for bulk $\mathrm{ZnS}$ [31]. From figure, it is noted that the absorption edges slightly shifted towards the lower energy side with increasing Mn upto 10\%. The band gap is found to decrease with increasing Mn concentration as shown in Fig. 8. The same shifts of the absorption edge with increasing Mn concentration from 0 to 9 at $\%$ at fixed size of $\mathrm{ZnS}$ nanoclusters were reported in literature [32,33].

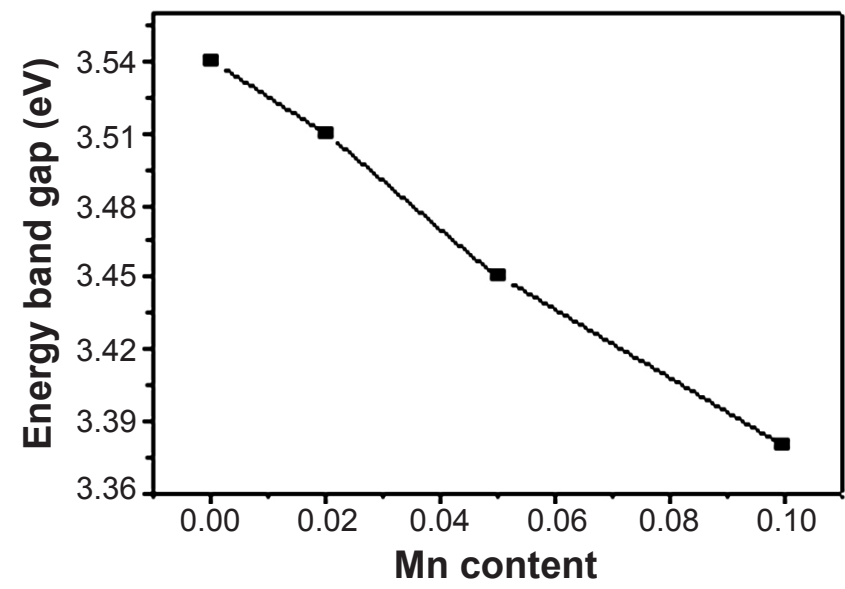

Figure 8: Energy band gap vs. Mn content of Mn doped and undoped $\mathrm{ZnS}$ samples.

[Figura 8: Gap da banda de energia vs. teor de Mn em amostras de ZnS pura e dopadas.]

But the variation of the band gap with the Mn concentration is the opposite is observed in $\mathrm{Mn}$ doped $\mathrm{CdS}$ nanocluster [34]. Levy et. al. reported that a minimum energy band gap was observed for 5-8\% of Mn concentration CdS samples. These changes of the band gap with Mn concentration are 
due to exchange interaction in confined region.

In our case, the size of $\mathrm{ZnS}$ nanoparticles were found to be in the range of $2-4 \mathrm{~nm}$ which is same as the exciton Bohr radius $(2.1 \mathrm{~nm})$ for a cubic $\mathrm{ZnS}$ structure. Hence the slight change of band gap may be assigned to weak quantum confinement effect in $\mathrm{ZnS}$ clusters. This small change in the band gap suggests that there is direct energy transfer between the semiconductor-excited states and the $3 \mathrm{~d}$ levels of $\mathrm{Mn}^{2+}$ ions [35].

\section{CONCLUSIONS}

The Mn doped $\mathrm{ZnS}$ nanocrystals were synthesized by a chemical method at room temperature. XRD patterns suggest that $\mathrm{Mn}$ ions go to $\mathrm{Zn}$ sites in the crystals without changing the Cubic structure. The lattice parameter slightly increases with increasing $\mathrm{Mn}$ concentration. We also observed that the average crystallite size is reduced with increasing $\mathrm{Mn}$ concentration; it may be due to a small grain growth in comparison with undoped $\mathrm{ZnS}$ nanocrystals. No secondary phases were observed upto $10 \%$ of Mn doped $\mathrm{ZnS}$ samples. It indicate that the homogenous substitution of $\mathrm{Mn}$ ions into the $\mathrm{ZnS}$ lattice structure. The TEM image of pure $\mathrm{ZnS}$ nanocrystals exhibits an average particle size of about 3-4 $\mathrm{nm}$. The TEM result is in good agreement with results of XRD. FTIR analysis confirms the formation of $\mathrm{ZnS}$ and Mn doped ZnS samples. The UV-VIS measurement shows the reduction in the band gap with increasing Mn content. It may be due to the direct energy transfer between the semiconductor-excited states and the $3 \mathrm{~d}$ levels of $\mathrm{Mn}^{2+}$ ions.

\section{ACKNOWLEDGEMENT}

B. N. Dole would like to thank University Grants Commission, New Delhi, India for financial assistance (Project No. F-37-563/2009/SR) and Prof. S. S. Shah for his encouragement.

\section{REFERENCES}

[1] H. Weller, Angew. Chem. Int. Ed. Engl. 32 (1993) 41-53. [2] A. P. Alivisatos, J. Phys. Chem. 100 (1996) 13226-39.

[3] P. Yang, M. Lu, D. Xu, D. Yuan, M. Pan, G. Zhou, Mater. Res. Bull. 36 (2001) 1301-06.

[4]J. Yu, H. Liu, Y. Wang, F. E. Fernandez, W. Jia, J. Lumin. 76-77 (1998) 252-55.

[5] R. N. Bhargava, D. Gallagher, T. Welker, J. Lumin. 6061 (1994) 275-80.

[6] K. Sooklal, B. S. Cullum, S. M. Angel, C. J. Murphy, J. Phys. Chem. 100 (1996) 4551-55.

[7] G. N. Lvanova, V. A. Kasiyan, N. D. Nedeoglo, D. D. Nedeogle, J. Lumin. 82 (1999) 277-83.

[8] A. A. Khosravi, M. Kundu, L. Jatwa, S. K. Deshpande, U. A. Bhagwat, M. Sastry, S. K. Kulkarni, Appl. Phys. Lett. 67 (1995) 2702-05.

[9] D. Denzler, M. Olschjewski, K. Sattler, Appl. Phys. Lett.
84 (1998) 2841-44.

[10] W. Chen, Z. Wang, Z. Lin, L. Lin, Appl. Phys. Lett. 70 (1997) 1466.

[11] L. Amirav, A. Amirav, E. Lifshitz, J. Phys. Chem. Lett. B 109 (2005) 9857-60.

[12] P. Balaz, E. Boldizarova, E. Godocikova, Briancin, J. Mater. Lett. 57 (2003) 1585-89.

[13] J. F. Xu, H. S. Jiw, Y. W. Tang, Du, Appl. Phys. A 66 (1998) 639-41.

[14] A. H. Souici, N. Keghouche, J. A. Delaire, H. Remita, M. Mostafavi, Chem. Phys. Lett. 422 (2006) 25-29.

[15] H. Yang, P. Hollway, J. Appl. Phys. 93 (2003) 586-93.

[16] J. H. Chung, C. S. Ah, D. J. Jang, J. Phys. Chem. B 105 (2001) 4128-32.

[17] I. Yu, I. Tetsukio, M. Seena, J. Phys. Chem. Solids 57 (1996) 373-79.

[18] K. Manzoor, S. R. Vadera, N. Kumar, T. R. N. Kutty, Mater. Chem. Phys. 82 (2003) 718-25.

[19] N. Karan, R. Suchitra, F. Singh, J. Cryst. Growth 268 (2004) 585-89.

[20] S. J. Xu, S. J. Chua, B. Liu, L. M. Gan, C. H. Chew, G. Q. Xu, Appl. Phys. Lett. 73 (1998) 478-81.

[21] M. Konishi, T. Isobe, M. Senna, J. Lumin. 93 (2001) $1-8$.

[22] L. X. Cao, J. H. Zhang, S. L. Ren, S. H. Huang, Appl. Phys. Lett. 80 (2002) 4300-03.

[23] M. W. Wang, L. D. Sun, C. H. Liu, C. S. Liao, C. H. Yan, Chin, J. Lumin. 20 (1999) 247.

[24] H. J. Yuan, X. Q. Yan, Z. X. Zhang, D. F. Liu, Z. P. Zhou, L. Cao, J. X. Wang, Y. Gao, L. Song, L. F. Liu, X. W. Zhao, X. Y. Dou, W. Y. Zhou, S. S. Xie, J. Cryst. Growth 271 (2004) 403-08.

[25] I. Chakraborty, S. P. Moulik, J. Nanopart. Res. 7 (2005) 237.

[26] B. S. Rema Devi, R. Raveendran, A. V. Vaidyan, Parama-J. Physics 68 (2007) 679-87.

[27] S. K. kurian, S. Sebastian, J. Mathew, K. C. George, Ind. J. Pure Appl. Phys. 42 (2004) 926-33.

[28] C. Jianfeny, L. Yaling, W. Yuhong, Y. Jimmy, C. Dapeng, Mater. Res. Bull. 39 (2004) 185-94.

[29] S. Sapra, N. Shanthi, D.D. Sarma, Phys. Rev. B 66 (2002) 205202-10.

[30] J. I. Pankove, "Optical Process in Semiconductors", Prentice-Hall Inc., USA, 36 (1971).

[31] B. Y. Geng, X. W. Liu, Q. B. Du, X. W. Wei, L. D. Zhang, Appl. Phys. Lett. 88 (2006) 163104-07.

[32] S. Sarpa, J. Nanda, A. Nanda, A. Anand, S.V. Bhat, D. D. Sarma, J. Nanosci. Nanotech. 3 (2003) 392.

[33] B. Bhattacharlee, D. Ganguli, K. Lakoubovskii, A. Stresmans, S. Chaudhari, Bull. Mater. Sci. 25 (2002) 17580.

[34] L. Levy, J. F. Hochepied, M. P. Pileni, J. Phys. Chem. 100 (1996) 18322-26.

[35] F. J. Brieler, M. Froba, L. Chem, P. J. Klar, W. Heimbrodt, H. A. Krug, V. Nidda, A. Loidl, Chem. Eur. J. 81 (2002) 185.

(Rec. 06/11/2012, Ac. 25/06/2013) 